PENELITIAN | RESEARCH

\title{
Culex vishnui Sebagai Vektor Filariasis Potensial di Kabupaten Kuantan Singingi Provinsi Riau
}

\author{
Culex vishnui as a Potential Vector Filariasis in Kuantan Singingi Regency Riau Province
}

\author{
Rahman Irpan Pahlepi ${ }^{1}{ }^{*}$, Santoso ${ }^{1}$, Vivin Mahdalena ${ }^{1}$, Marini ${ }^{1}$ \\ 1Balai Litbang Kesehatan Baturaja, Badan Litbang Kesehatan, Kemenkes RI \\ Jl. Ahmad Yani KM 7 Kemelak 32111, Baturaja-Ogan Komering Ulu, Sumatera Selatan, Indonesia
}

\begin{abstract}
Kuantan Singingi District is one of the endemic areas of filariasis in Riau Province. Mass treatment activities have been carried out, but the results of the 2016 TAS-1 with Brugia Rapid Test still showed 11 positive children. This condition indicates that new transmission in Kuantan Singingi District is still happening. The purpose of this study was to determine the mosquito species that have the potential to become filariasis vector and determine the types of potential breeding habitats for mosquito larvae. Data collection has been carried out in Pulau Panjang Cerenti Village, Cerenti Subdistrict and Sukadamai Village, Singingi Hilir District in September and November 2017. Catching mosquitoes held for 12 hours starting at 18.00 -06.00 Western Indonesia Time, using the modification of human landing collection double net method. Mosquito collection was done twice, with an interval of one month, at three points/locations for two consecutive nights. There were 24 species of mosquito caught in the two villages. The most dominant species in Pulau Panjang Village was Culex vishnui (54.89\%) with indoor and outdoor MHD were 4.5 and 16.08 species/man/hour respectively. Whereas in Sukadamai Village, Culex quinquefasciatus (95.42\%) with indoor and outdoor MHD were 23.58 and 19.08 species/man/hour respectively. Polymerase Chain Reaction (PCR) examination results on mosquitoes collected in Sukadamai Village showed DNA of B. malayi microfilaria in $\mathrm{Cx}$. vishnui. So, it was concluded that $\mathrm{Cx}$. vishnui had the potential to become a filariasis vector. Breeding habitats that were found mostly were fish ponds that were no longer used, puddles, and swamps. Riverfront habitats were only found in Pulau Panjang Village.
\end{abstract}

Keywords: Filariasis, Culex vishnui, Potential vector, Habitats, Kuantan Singingi

\begin{abstract}
Abstrak. Kabupaten Kuantan Singingi merupakan salah satu wilayah endemis filariasis di Provinsi Riau. Kegiatan pengobatan massal telah dilakukan, namun hasil TAS-1 tahun 2016 dengan Brugia Rapid Test masih menunjukkan 11 anak positif. Kondisi ini menunjukkan bahwa penularan baru di Kabupaten Kuantan Singingi masih terjadi. Tujuan penelitian ini adalah untuk mengetahui spesies nyamuk yang berpotensi menjadi vektor filariasis dan mengetahui jenis-jenis habitat perkembangbiakan potensial bagi larva nyamuk. Pengumpulan data telah dilakukan di Desa Pulau Panjang Cerenti Kecamatan Cerenti dan Desa Sukadamai Kecamatan Singingi Hilir pada bulan September dan November 2017. Penangkapan nyamuk dilakukan selama 12 jam dimulai dari pukul 18.00-06.00 WIB, menggunakan metode modifikasi human landing collection double net. Penangkapan nyamuk dilakukan sebanyak dua kali, dengan selang waktu satu bulan, pada tiga titik/lokasi selama dua malam berturut-turut. Spesies nyamuk yang tertangkap di dua desa sebanyak 24 spesies. Spesies yang paling dominan di Desa Pulau Panjang yaitu Culex vishnui (54,89\%) dengan MHD di luar dan dalam rumah sebesar 4,5 dan 16,08 nyamuk/orang/jam. Sedangkan di Desa Sukadamai yaitu Cx. quinquefasciatus $(95,42 \%)$ dengan MHD di luar dan dalam rumah sebesar 23,58 dan 19,08 nyamuk/orang/jam. Hasil pemeriksaan PCR (Polymerase Chain Reaction) pada nyamuk yang tertangkap di Desa Sukadamai menunjukkan DNA mikrofilaria $B$. malayi pada nyamuk $C x$. Vishnui. Sehingga disimpulkan bahwa nyamuk tersebut berpotensi menjadi vektor filariasis. Habitat perkembangbiakan yang ditemukan sebagian besar adalah kolam ikan yang sudah tidak digunakan lagi, genangan air, dan rawa. Habitat tepi sungai hanya ditemukan di Desa Pulau Panjang.
\end{abstract}

Kata Kunci: Filariasis, Culex vishnui, Vektor potensial, Habitat, Kuantan Singingi

Naskah masuk: 26 Maret 2020 | Revisi: 24 Mei 2020 | Layak terbit: 10 Juni 2020

*Corresponding author. E-mail: irpan_bta@yahoo.co.id | Tlp : +62 81278020435 


\section{PENDAHULUAN}

Sampai saat ini filariasis masih menjadi permassalahan di Indonesia. Penyakit ini tersebar luas di pedesaan dan perkotaan serta dapat menyerang semua golongan tanpa mengenal usia dan jenis kelamin. ${ }^{1,2}$ Filariasis disebabkan oleh berbagai macam jenis nyamuk. Sampai saat ini di Indonesia telah teridentifikasi 23 spesies nyamuk dari lima genus yang telah terkonfirmasi sebagai vektor filariasis yaitu Mansonia, Anopheles, Culex, Aedes, dan Armigeres. ${ }^{3}$ Di Kabupaten Kuantan Singingi Provinsi Riau telah terkonfirmasi empat spesies nyamuk vektor filariasis yaitu Mansonia uniformis, Ma. dives, Ma. bonneae, Anopheles nigerrimus. ${ }^{3}$

Jumlah kasus kronis filariasis di Indonesia pada tahun 2016 dilaporkan sebanyak 13.009 kasus dan mengalami penurunan pada tahun 2017 di mana terdapat 12.677 kasus kronis. ${ }^{4}$ Kegiatan pemberian obat pencegahan massal (POPM) untuk memutuskan rantai penularan filariasis di Indonesia telah dilakukan sejak tahun 2006, dengan cakupan pengobatan berkisar antara 15,40\% (tahun 2006) hingga 78\% (tahun 2019). Target minimal cakupan POPM filariasis per tahun minimal $65 \%$ dari total penduduk kabupaten. Sebanyak 118 kabupaten telah selesai melakukan POPM selama 5 tahun putaran dan 30 kabupaten telah dinyatakan eliminasi filariasis. ${ }^{5}$

Pada tahun 2017 Provinsi Riau termasuk tiga besar di Indonesia dengan 83\% kabupaten/kota masuk ke dalam daerah endemis. ${ }^{4}$ Kabupaten Kuantan Singingi merupakan satu di antara daerah yang memiliki massalah filariasis di Provinsi Riau. Pengobatan massal filariasis di Kabupaten Kuantan Singingi telah dilakukan tahun 2011-2015. Tahun 2016, Kabupaten Kuantan Singingi dinyatakan lulus evaluasi TAS-1 (Transmission Assesment Survey) melalui pemeriksaan darah tepi anak kelas 1-2 sekolah dasar (SD) menggunakan brugia rapid test $^{T M}$, namun masih ditemukan kasus positif pada 11 anak tersebut. ${ }^{6}$

Periode evaluasi TAS membutuhkan waktu yang lama terhitung 6 tahun setelah POPM sampai suatu wilayah mendapatkan sertifikasi eliminasi filariasis. Kabupaten Kuantan Singingi telah berhasil lulus pada dua kali evaluasi yaitu TAS-1 dan TAS-2 pada tahun 2018 dan akan menghadapi pelaksanaan TAS-3 pada tahun $2020 .^{7}$ Selama periode tersebut, maka penting untuk melakukan kegiatan surveilans secara rutin agar di wilayah tersebut benar-benar tidak terjadi penularan filariasis kembali. Kegiatan surveilans filariasis diantaranya adalah melaksankan survei vektor untuk mengetahui nyamuk yang berpotensi sebagai penular filariasis. ${ }^{8}$ Penemuan kasus positif pada evaluasi TAS di wilayah ini ditambah dengan kurangnya data entomologi mengenai nyamuk vektor filariasis di Kabupaten Kuantan Singigi, maka penelitian ini dilakukan. Tujuan penelitian adalah mengidentifikasi spesies nyamuk yang berpotensi menjadi vektor filariasis serta habitat perkembangbiakannya di Kabupaten Kuantan Singingi Provinsi Riau.

\section{BAHAN DAN METODE}

Penelitian ini merupakan bagian dari studi evaluasi filariasis di Kabupaten Kuantan Singingi.7,9 Daerah penelitian adalah Desa Sukadamai, Kecamatan Singingi Hilir dan Desa Pulau Panjang, Kecamatan Cerenti, Kabupaten Kuantan Singingi Provinsi Riau. Kriteria pemilihan daerah penelitian adalah daerah/desa paling banyak terdapat anak yang positif pada saat pemeriksaan darah tepi menggunakan brugia rapid test ${ }^{T M}$ yang dilaksanakan Subdit $\mathrm{P}_{2}$ Filariasis tahun 2016. Jumlah anak SD yang positif di kedua desa tersebut sebanyak 2 orang dan kedua lokasi penelitian merupakan spot area. Kegiatan pengambilan sampel dilaksanakan sebanyak dua kali yaitu pada bulan September dan November 2017. Jenis penelitian adalah potong lintang (cross sectional). Populasi dalam penelitian ini adalah seluruh nyamuk yang ada di wilayah Desa Sukadamai dan Desa Pulau Panjang. Sampel penelitian adalah semua nyamuk yang tertangkap selama penelitian.

Metode yang digunakan adalah modifikasi human landing collection (HLC) dengan menggunakan kelambu (double net). Metode ini dinilai lebih aman untuk penangkapan nyamuk menggunakan kolektor/manusia. ${ }^{10}$ Penangkapan nyamuk dilakukan di tiga titik/lokasi selama dua malam berturut-turut. Penangkapan nyamuk dilakukan di tiga rumah dan masing-masing rumah di letakkan kelambu di dalam dan luar rumah. Penangkapan nyamuk menggunakan kolektor sudah mendapatkan persetujuan etik dari Komisi etik Badan Litbang Kesehatan Kemenkes RI (No: LB.02.01/2/KE.167/2017). Kelambu yang dipasang sebanyak dua kelambu. Kelambu bagian luar berbentuk persegi panjang dengan ukuran $200 \mathrm{~cm} \times 150 \mathrm{~cm} \times 150 \mathrm{~cm}$ dan kelambu bagian dalam berbentuk prisma segitiga dengan ukuran $150 \mathrm{~cm} \times 90 \mathrm{~cm} \times 120 \mathrm{~cm}$. Kelambu bagian luar dibiarkan terbuka bagian bawahnya supaya nyamuk dapat masuk kedalam kelambu besar. Kolektor berada di kelambu kecil bagian dalam. Kolektor mengumpulkan nyamuk yang hinggap, baik yang di kelambu luar ataupun dalam kelambu setiap 10 menit selama lima menit (20 menit setiap jam nya). Penangkapan 
dimulai sore hari pukul 18.00 WIB sampai esok hari pukul 06.00 WIB. Nyamuk yang tertangkap dan telah dimatikan menggunakan kloroform di identifikasi menggunakan kunci identifikasi nyamuk. ${ }^{11,12}$

Setelah diidentifikasi nyamuk dipisahkan dengan mengambil bagian kepala dan thorax kemudian dikumpulkan dalam microtube effendorf 1,5 ml. Untuk mengetahui DNA cacing filariasis dalam tubuh nyamuk digunakan teknik Polymerase Chain Reaction (PCR) sehingga hanya nyamuk betina parous yang akan diperiksa keberadaan larva cacing filaria. ${ }^{13,14}$ Proses pemeriksaan PCR dilakukan di Laboratorium Upaya Kesehatan Masyarakat Badan Litbang Kesehatan. Pemeriksaan dilakukan secara pooling berdasarkan spesies dan lokasi. Proses awal untuk mendapatkan material DNA adalah dengan mengumpulkan nyamuk yang telah ditangkap dan diidentifikasi, kemudian dikumpulkan dalam satu microtube. Masingmasing microtube diisikan sebanyak 1-5 nyamuk ditambahkan $500 \mu \mathrm{l}$ Phospate Buffer Saline (PBS) untuk mendapatkan supernatant. Metode pemeriksaan selanjutnya adalah menggunakan teknik RT-iiPCR yang merupakan salah satu teknik deteksi molekuler cepat dengan menggunakan mesin portable. Tahapan pemeriksaan molekuler meliputi ekstraksi asam nukleat menggunakan taco $^{\text {tm }}$ Pre-load DNA ekstraksi kit (GeneReach Biotech) untuk mendapatkan DNA product. Tahapan selanjutnya adalah amplifikasi menggunakan $5 \mu \mathrm{l}$ DNA product yang ditambahkan ke dalam $50 \mu \mathrm{l}$ premix buffer. Untuk kontrol positif (BM dan WB) diambil $5 \mu \mathrm{l}$ dari masing-masing microtube, kemudian dimasukkan ke dalam premix bufer. Masing-masing campuran yang telah alikuot kemudian dimasukkan ke dalam $\mathrm{R}$ tube ${ }^{\mathrm{TM}}$ dan dilakukan sentrifugasi sebentar $( \pm 1$ menit). Selanjutnya, dimasukkan ke dalam mesin Nucleic Acid Analyzer PCR selama \pm 60 menit. Hasil kualitatif ditampilkan pada layar pada akhir program dengan menunjukkan + (positif), (negatif) dan tanda "?" (ambigu). Apabila hasil menunjukkan tanda "?" maka sampel harus dilakukan uji ulang. ${ }^{15}$

Selain survei nyamuk, juga dilakukan survei habitat. Dalam survei ini dilakukan pengamatan dan pencatatan habitat yang meliputi jenis habitat, genus nyamuk, jarak ke pemukiman, habitat spesifik dan vegetasi habitat. Nyamuk yang tertangkap dianalisis secara deskriptif dan disajikan dalam bentuk tabel dan grafik. Data yang diperoleh dianalisis untuk mengetahui parameter densitas nyamuk. Penghitungan parameter densitas nyamuk dihitung dengan persamaan sebagai berikut: ${ }^{3}$ Man Hour Density (MHD) menyatakan kepadatan nyamuk yang kontak dengan manusia dalam satu jam (nyamuk/orang/jam). Kelimpahan nisbi adalah perbandingan antara banyaknya nyamuk suatu spesies dengan jumlah nyamuk dari berbagai spesies yang tertangkap, dan dinyatakan dalam persentase. Angka frekuensi nyamuk tertangkap adalah perbandingan antara jumlah suatu spesies nyamuk ditemukan dalam penangkapan dan banyaknya penangkapan. Angka dominansi spesies diperoleh dari hasil perkalian kelimpahan nisbi dan frekuensi nyamuk tersebut tertangkap.

$$
\begin{aligned}
& \text { MHD }=\frac{\text { Jumlah nyamuk tertangkap }}{\text { Jumlah penangkap x jumlah jam penangkapan }} \\
& \text { Kelimpahan nisbi }=\frac{\text { Jumlah nyamuk spesies tertentu }}{\text { Jumlah nyamuk tertangkap }} \times 100 \% \\
& \text { Frekuensi }=\frac{\text { Jumlah penangkapan diperolehnya spesies tertentu }}{\text { Jumlah penangkapan nyamuk }} \\
& \text { Dominansi spesies }=\text { Kelimpahana nisbi } x \text { Frekuensi nyamuk tertangkap }
\end{aligned}
$$

\section{HASIL}

\section{Keragaman Spesies Nyamuk Tertangkap}

Hasil penangkapan nyamuk di dua lokasi penangkapan didapatkan sebanyak 1.235 nyamuk, yang teridentifikasi atas enam genus dan 24 spesies. Hasil penangkapan di Desa Pulau Panjang didapatkan sebanyak 23 spesies dan yang paling banyak tertangkap yaitu $C x$. vishnui, sedangkan di Desa Sukadamai didapatkan nyamuk sebanyak 10 spesies dengan spesies nyamuk yang paling banyak tertangkap yaitu $C x$. quinquefasciatus. Jumlah nyamuk yang tertangkap di Desa Sukadamai lebih banyak daripada nyamuk yang tertangkap di Desa Pulau Panjang. Namun, bila dilihat dari jenis nyamuk yang tertangkap, di Desa Pulau Panjang lebih bervariasi dibandingkan dengan nyamuk yang tertangkap di Desa Sukadamai (Tabel 1 dan Tabel 2).

\section{Parameter Densitas Nyamuk Tertangkap}

Kepadatan nyamuk yang tertangkap saat akan mengisap darah manusia di Desa Pulau Panjang menunjukan spesies dengan MHD tertinggi adalah $C x$. vishnui, yaitu dengan nilai masing-masing 4,50 nyamuk/orang/jam di dalam rumah dan 16,08 nyamuk/orang/jam di luar rumah. Sedangkan di Desa Sukadamai spesies dengan MHD tertinggi adalah $C x$. quinquefasciatus dengan nilai masing-masing 23,58 nyamuk/orang/jam di dalam rumah dan 19,08 nyamuk/orang/jam di luar rumah. Hasil perhitungan dominansi spesies tertinggi Desa Pulau Panjang baik di luar dan dalam rumah adalah $C x$. vishnui sedangkan di Desa Sukadamai adalah Cx. quinquefasciatus (Tabel 1 dan Tabel 2). 


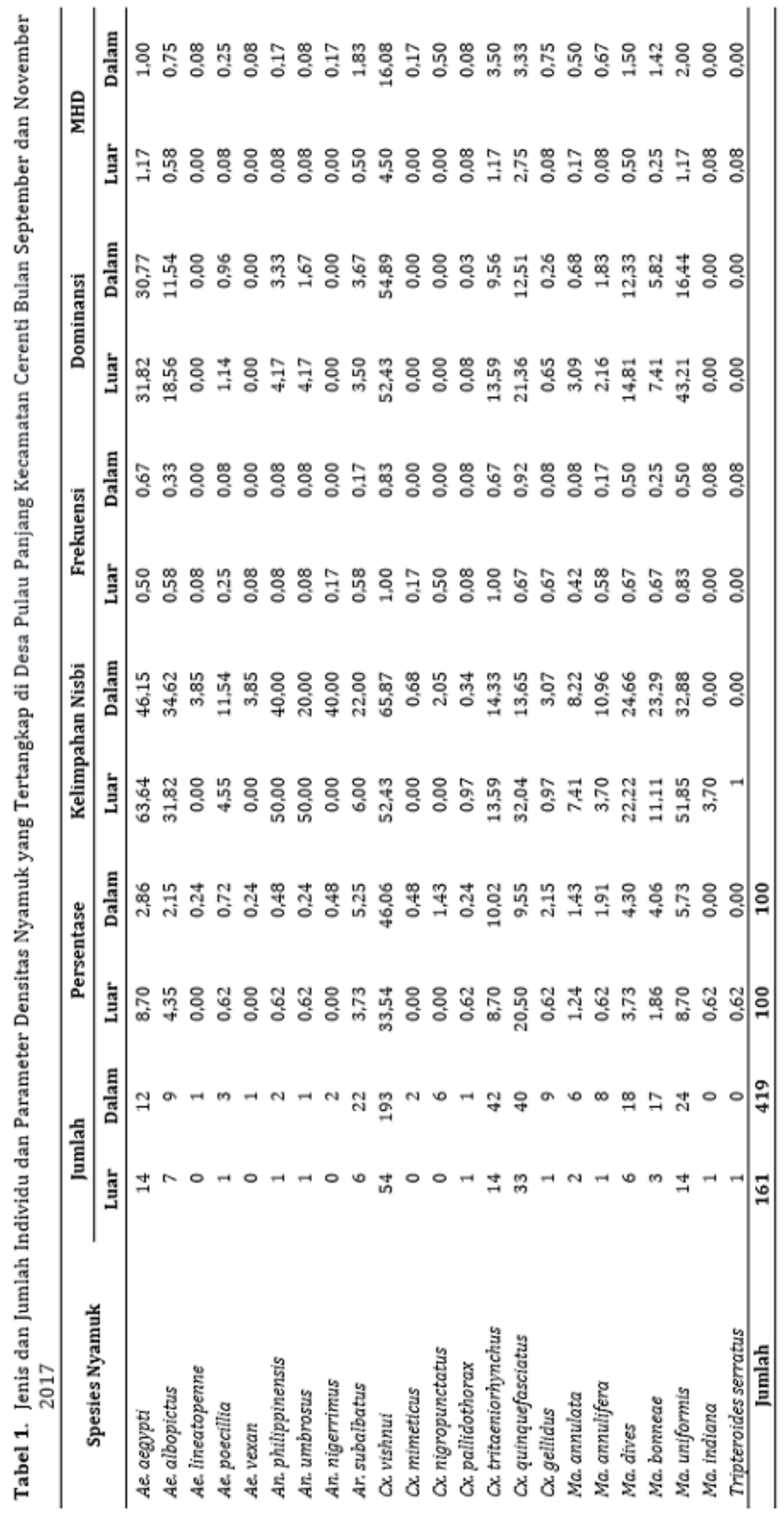




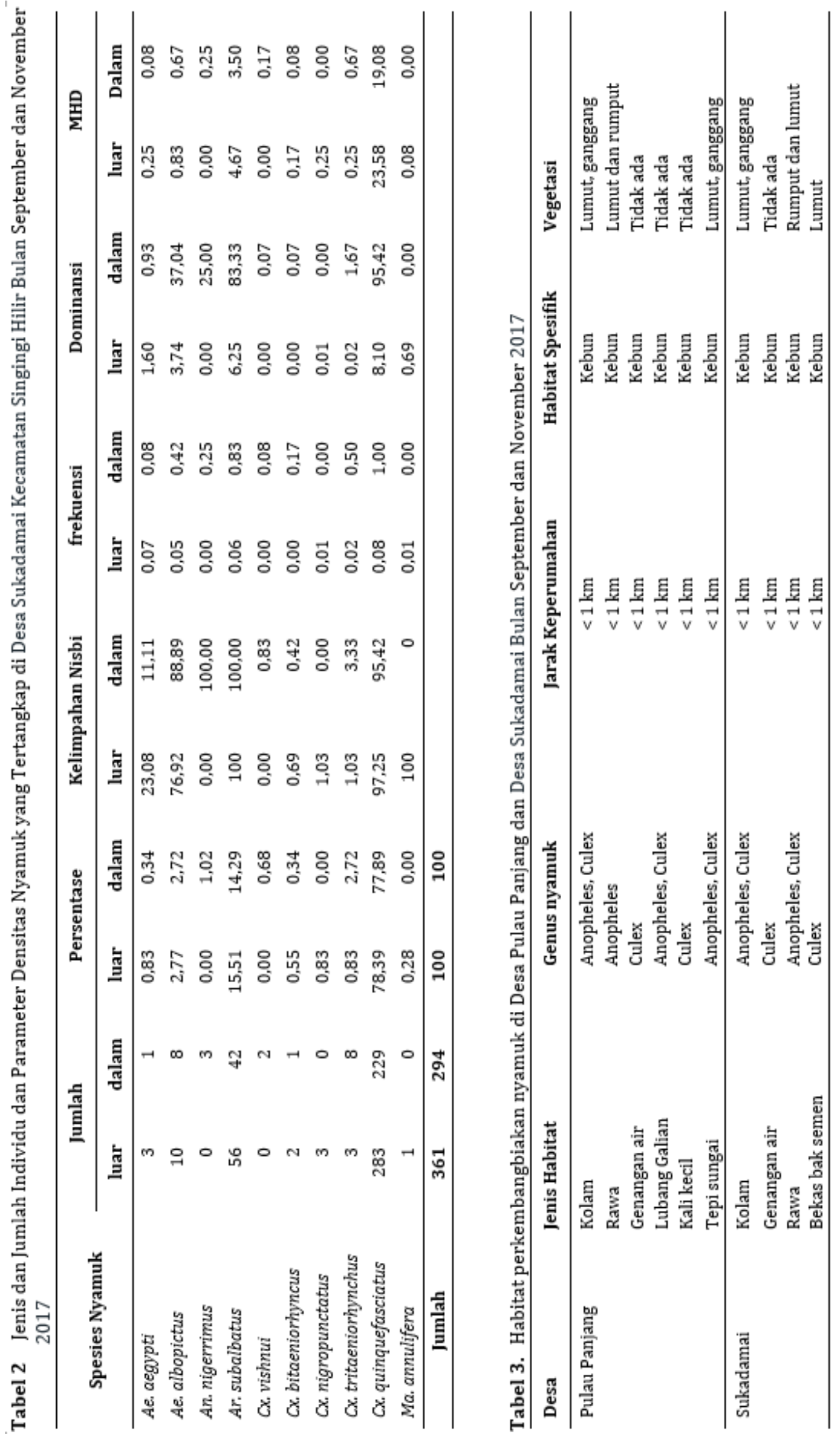




\section{Habitat Nyamuk}

Hasil survei habitat perkembangbiakan nyamuk yang ditemukan di Desa Pulau Panjang dan di Desa Sukadamai sebagian besar adalah kolam ikan yang sudah tidak digunakan lagi, genangan air, dan rawa. Habitat tepi sungai hanya ditemukan di Desa Pulau Panjang. Genus nyamuk yang teridentifikasi di dua desa yaitu Anopheles dan Culex (Tabel 3).

\section{Perilaku Nyamuk yang Berpotensi Menjadi Vektor}

Gambar 1 menunjukkan fluktuasi nyamuk yang tertangkap di Desa Pulau Panjang. Aktivitas tersebut menampilkan nyamuk yang telah terkonfimasi sebagai vektor di Provinsi Riau yaitu Ma. uniformis, Ma. dives, Ma. bonneae, An. nigerrimus serta nyamuk yang telah terkonfirmasi sebagai vektor potensial pada penelitian ini yaitu $C x$. vishnui. Gambar 2 juga menunjukan fluktuasi nyamuk yang tertangkap di Desa Sukadamai, Gambar tersebut juga menampilkan nyamuk yang telah terkonfirmasi sebagai vektor di Provinsi Riau dan nyamuk dengan nilai MHD tertinggi.

\section{Deteksi Cacing Filaria (PCR)}

Hasil pemeriksaan PCR pada nyamuk yang tertangkap di Desa Sukadamai diketahui bahwa pada nyamuk $C x$. vishnui ditemukan DNA mikrofilaria $B$. malayi sehingga $C x$. vishnui berpotensi menjadi vektor filariasis, sedangkan di Desa Pulau Panjang tidak ditemukan nyamuk yang berpotensi vektor.

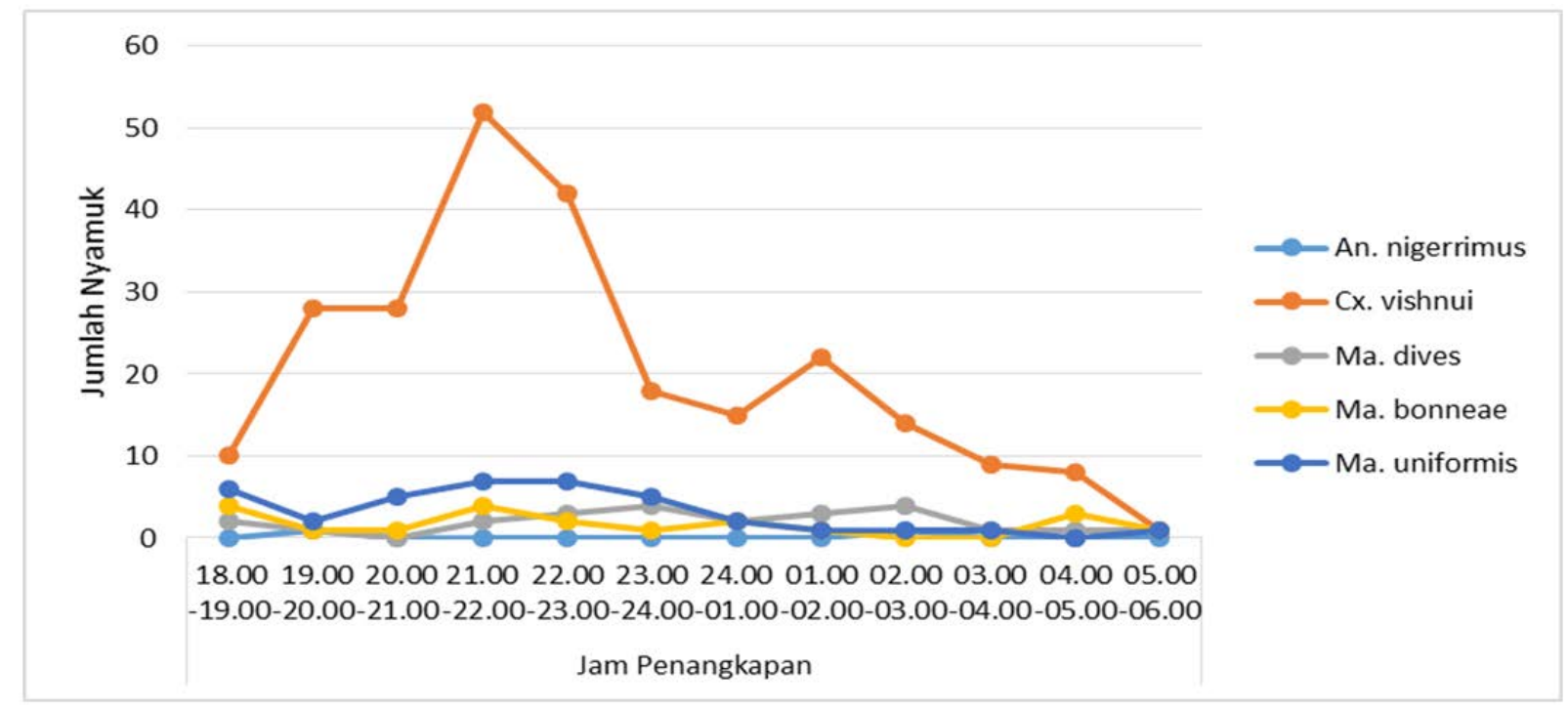

Gambar 1. Fluktuasi aktivitas nyamuk yang berpotensi menjadi vektor filariasis di Desa Pulau Panjang Kabupaten Kuantan Singingi bulan September dan November 2017

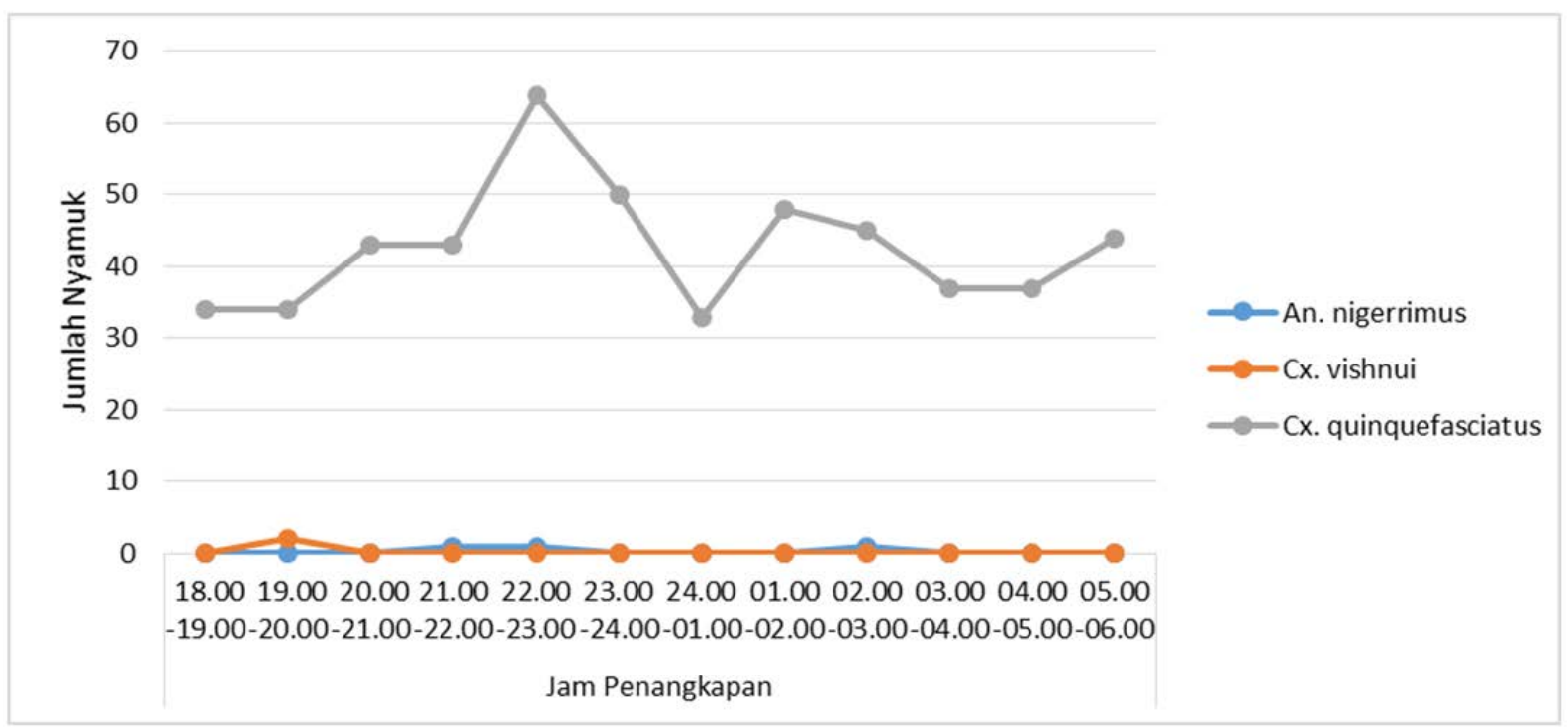

Gambar 2. Fluktuasi aktivitas nyamuk yang berpotensi menjadi vektor filariasis di Desa Sukadamai Kabupaten Kuantan Singingi bulan September dan November 2017 


\section{PEMBAHASAN}

Nyamuk yang tertangkap di dua desa wilayah penelitian didominasi oleh genus Culex. Culex vishnui lebih banyak ditemukan di Desa Pulau Panjang sedangkan di Desa Sukadamai yang dominan adalah $C x$. quinquefasciatus. Hal ini dikarenakan sebagian besar lokasi penelitian merupakan daerah perkebunan kelapa sawit dan hutan primer yang mendukung bagi habitat nyamuk Culex. Lingkungan yang banyak ditemukan keberadaan semak, genangan air, rawa, menjadi tempat strategis bagi nyamuk Culex untuk beristirahat maupun berkembangbiak sehingga mendukung dalam kepadatan nyamuk. ${ }^{16}$ Berdasarkan teori Service (2016), nyamuk Culex mempunyai kebiasaan beristirahat dan bertelur pada air yang tergenang dan rawa-rawa di sekitar lingkungan. ${ }^{17}$ Penelitian yang dilakukan oleh Suharno (2015) menunjukkan bahwa keadaan lingkungan yang berupa perkebunan karet, perkebunan cokelat, rawa berpotensi menjadi tempat berkembangbiak yang potensial bagi vektor filariasis. ${ }^{18}$

Selain itu, spesies lain yang menjadi vektor filariasis juga ditemukan diantaranya adalah Mansonia. Nyamuk Mansonia yang merupakan vektor utama filariasis $B$. malayi hanya tertangkap sebanyak $17,2 \%$ di Desa Pulau Panjang dan 0,2\% di Desa Sukadamai. Hal ini disebabkan karena karakteristik lingkungan di Desa Sukadamai yang sebagian besar adalah perkebunan sawit dan cenderung kering, sehingga kurang disukai oleh nyamuk Mansonia. Menurut Pratiwi et. al., keanekaragaman dan kelimpahan nyamuk Mansonia di suatu daerah berkaitan erat dengan karakteristik lingkungan, seperti suhu, kelembapan, parameter air, dan spesies tanaman serta ketersediaan tempat berkembang biak. ${ }^{19}$

Pada penelitian ini juga ditemukan nyamuk An. nigerrimus dengan persentase tertangkap yang rendah (1\%). Meskipun persentase tertangkap nyamuk Anopheles di wilayah penelitian tergolong rendah, namun tetap memerlukan perhatian lebih dikarenakan kemungkinan terjadinya penularan filariasis masih ada dan risiko penularan semakin tinggi dengan ditemukannya kasus positif $B$. malayi di wilayah penelitian. Menurut Adyana et. al., nyamuk Anopheles merupakan vektor filariasis di Sumba Timur dan Sumba Barat Daya yang ditandai dengan ditemukannya larva filarial didalam tubuh nyamuk An. vagus dan $A n$. sundaicus dengan menggunakan metode pembedahan. ${ }^{20}$
Hasil analisis dari kepadatan nyamuk yang tertangkap di Desa Pulau Panjang menunjukkan bahwa $C x$. vishnui mempunyai MHD tertinggi di dalam rumah dengan nilai 16,08 nyamuk/ orang/jam sedangkan di Desa Sukadamai MHD tertinggi di luar rumah adalah $C x$. quinquefasciatus dengan nilai 23,58 nyamuk/ orang/jam. Hasil penelitian Portunasari et. al. yang diperkuat oleh Mulyaningsih et. al. menyatakan bahwa besarnya kepadatan nyamuk akan meningkatkan frekuensi kontak antara vektor dan manusia. Populasi vektor yang melimpah di alam akan memperbesar peluang terjadinya kontak antara manusia dengan vektor, sehingga risiko penularan semakin meningkat. ${ }^{21,22}$ Di Provinsi Aceh, Kabupaten Aceh Barat, Pidie dan Aceh Timur, nyamuk yang berpotensi sebagai vektor filariasis adalah $C x$. vishnui. ${ }^{23}$

Nyamuk yang tertangkap di Desa Pulau Panjang banyak didapatkan di dalam rumah, berbanding terbalik dengan nyamuk yang tertangkap di Desa Sukadamai, lebih dominan di luar rumah. Puncak aktivitas mengisap darah $C x$. vishnui di Desa Pulau Panjang pada pukul 21.0022.00 WIB, sedangkan di Desa Sukadamai pada pukul 22.00-23.00 WIB. Hal ini berbeda dengan penelitian sebelumnya yang menunjukan puncak aktivitas mengisap darah $C x$. vishnui pada pukul 02.00-03.00 WIB. ${ }^{24}$ Penelitian lain menunjukkan bahwa aktivitas mengisap darah $C x$. vishnui meningkat pada pukul 18.00-20.00 WIB. ${ }^{25}$

Penularan filariasis dipengaruhi oleh beberapa faktor, diantaranya adanya penderita positif mikrofilaria, kepadatan vektor penular, perilaku masyarakat serta faktor ekologi. Salah satu syarat nyamuk dinyatakan sebagai vektor apabila kepadatannya lebih tinggi di bandingkan dengan jenis nyamuk yang lain. ${ }^{3}$ Hal tersebut agak berbeda dengan hasil penelitian ini, $C x$. vishnui merupakan spesies yang paling dominan di Desa Pulau Panjang namun hasil PCR negatif $B$. malayi. Sedangkan kepadatan $C x$. vishnui di Desa Sukadamai rendah 0,68\%, namun hasil PCR dinyatakan positif $B$. malayi. Secara umum, kondisi kepadatan $C x$. vishnui di Desa Pulau Panjang sejalan dengan penelitian sebelumnya yang menunjukan $C x$. vishnui memiliki kepadatan tinggi, kelimpahan relatif tinggi, frekuensi tinggi, dan dominansi tinggi tetapi tidak berperan dalam transmisi filariasis limfatik. ${ }^{24}$

Hasil uji PCR dari nyamuk CX. vishnui yang tertangkap di Desa Sukadamai terdeteksi DNA mikrofilaria B. malayi. Pemeriksaan PCR pada nyamuk tidak dilakukan secara individu melainkan per spesies sehingga tidak diketahui berapa persen nyamuk yang positif $B$. malayi. Hal ini sesuai dengan hasil analisis yang dilakukan di 
Kabupaten Meranti Provinsi Riau dari tahun 2009-2014 bahwa 39,5\% kejadian filariasis di Kabupaten Meranti Provinsi Riau disebabkan oleh B. malayi. ${ }^{26}$ Sampai saat ini $C x$. quinquefasciatus telah dilaporkan menjadi vektor utama filariasis, sedangkan laporan mengenai $C x$. vishnui sebagai vektor utama ataupun vektor potensial filariasis masih belum ada. Pemeriksaan nyamuk secara PCR dapat digunakan sebagai alternatif untuk mengidentifikasi nyamuk yang berperan sebagai vektor sehingga dapat digunakan sebagai dasar pengendalian vektor dalam mendukung eliminasi filariasis di daerah dengan tingkat penularan yang tinggi sehingga intervensi pengendalian dapat dilakukan secara efektif. ${ }^{27,8}$ Namun, pembedahan tubuh nyamuk tetap merupakan gold standard dalam penentuan vektor filariasis.

Lingkungan sangat berpengaruh terhadap distribusi kasus filariasis dan mata rantai penularannya. Daerah endemis $B$. malayi sebagian besar adalah daerah dengan hutan rawa, sepanjang sungai atau badan air lain yang di tumbuhi tanaman air. ${ }^{4}$ Pada penelitian ini habitat nyamuk yang ditemukan seperti rawa, genangan air dan kolam berada di sekitar pemukiman penduduk dengan jarak kurang lebih satu $\mathrm{km}$ dari pemukiman penduduk. Tinggal dekat dengan perkebunan ( $\leq 200$ meter) berisiko terinfeksi filariasis 19.46 kali dibandingkan responden yang tidak bertempat tinggal dekat dengan perkebunan. ${ }^{28}$ Kondisi sekitar rumah penduduk yang didominasi oleh sungai, rawa, perkebunan menjadi tempat yang potensial untuk perkembangbiakan nyamuk. ${ }^{29}$ Munawwaroh dan Pawenang (2017), menyebutkan bahwa keberadaan genangan air, adanya semak-semak dan adanya tanaman air menjadi faktor yang menentukan perkembangbiakan potensial nyamuk vektor filariasis. $^{30}$

Filariasis B. malayi termasuk dalam zoonosis, yaitu penyakit yang dapat menular pada hewan. Hasil penelitian sebelumnya mendapatkan kucing yang positif B. malayi. ${ }^{31}$, Hasil penelitian mengenai faktor reservoir sebagai transmisi $B$. malayi yang dilakukan oleh Santoso et al. pada 2019 tidak ditemukannya reservoir yang positif $B$. malayi. $^{32}$ Dengan ditemukannya DNA cacing filarial di dalam tubuh nyamuk $C x$. vishnui yang tertangkap dan berdasarkan hasil observasi lingkungan juga ditemukan habitat potensial perkembangbiakan nyamuk. Hal ini menunjukkan bahwa transmisi penularan filariasis di Kabupaten Kuantan Singingi masih ada dan perlu mendapatkan perhatian dari semua pihak untuk memutus rantai penularan tersebut. Perlu dilakukan sosialisasi kepada masyarakat mengenai filariasis serta pemantauan secara berkala terhadap habitat yang berpotensi menjadi habitat perkembangbiakan nyamuk..

\section{KESIMPULAN}

Nyamuk dominan yang tertangkap di lokasi penelitian adalah $C x$. vishnui dan $C x$. quinquefasciatus. Perilaku $C x$. vishnui lebih senang mengisap darah di dalam rumah dengan puncak aktivitas mengisap darah pukul 21.0022.00, sedangkan $C x$. quinquefasciatus lebih senang mengisap darah di luar rumah dengan puncak aktivitas mengisap darah pukul 22.0023.00. Hasil pemeriksaan PCR pada $C X$. vishnui di Desa Sukadamai ditemukan DNA mikrofilaria $B$. malayi. Hal ini menunjukan bahwa di Kabupaten Kuantan Singingi masih berpotensi untuk terjadinya transmisi filariasis.

\section{UCAPAN TERIMA KASIH}

Penulis mengucapkan terima kasih kepada Dinas Kesehatan Kabupaten Kuantan Singingi, Kepala Badan Litbang Kesehatan, Kepala Balai Penelitian dan Pengembangan Kesehatan Baturaja, teman-teman Balai Litbang Kesehatan Baturaja serta semua pihak yang telah membantu menyelesaikan penelitian ini

\section{KONTRIBUSI PENULIS}

Semua penulis pada artikel ini Rahman Irpan Pahlepi, Santoso, Vivin Mahdalena, Marini adalah kontributor utama.

$\begin{array}{lll}\text { Konsep } & : & \mathrm{RIP}, \mathrm{S} \\ \text { Kurasi Data } & : & \mathrm{VM}, \mathrm{M} \\ \text { Analisis Data } & : & \mathrm{RIP}, \mathrm{S} \\ \text { Investigasi } & : & \mathrm{RIP}, \mathrm{S}, \mathrm{VM}, \mathrm{M} \\ \text { Manajemen Proyek } & : & \mathrm{RIP}, \mathrm{S} \\ \text { Sumber Daya } & : & \mathrm{VM}, \mathrm{M} \\ \text { Pengawasan } & : & \mathrm{S} \\ \text { Validasi } & : & \mathrm{EAF} \\ \text { Visualisasi } & : & \mathrm{VM}, \mathrm{M} \\ \text { Menulis-Pembuatan } & : & \mathrm{RIP}, \mathrm{S} \\ \text { Draft } & & \end{array}$

\section{DAFTAR RUJUKAN}

1. Dwi N. Dinamika penularan dan faktor risiko kejadian filariasis di Kecamatan Kumpeh Kabupaten Muaro Jambi tahun 2014. J Penelit Univ Jambi Seri Sains. 2016;18(1):56-63. 
2. Yanuarini C. Faktor-faktor yang berhubungan dengan kejadian filariasis di Puskesmas Tirto I Kabupaten Pekalongan. FIKkeS J keperawatan. 2015;8(1):1-14.

3. Kementerian Kesehatan Republik Indonesia. Peraturan Menteri Kesehatan Repubik Indonesia Nomor 94 Tahun 2014, Tentang Penanggulangan Filariasis. Indonesia; 2014:1-118.

4. Infodatin. Menuju Indonesia bebas filariasis. Jakarta; 2018.

5. Dirjen P2TVZ Kemkes. Strategi Percepatan penanggulangan filariasis dan kecacingan di Indonesia Situasi filariasis dan cacingan di Indonesia. Jakarta; 2020.

6. Dinkes Kepulauan Riau. Profil Kesehatan Provinsi Kepulauan Riau. Kuantan Singingi: Dinas Kesehatan Kabupaten Kuantan Singingi; 2016.

7. Santoso, Pahlepi IR, Suryaningtyas $\mathrm{NH}$ Yenni A, Marini, Magdalena V D. Laporan akhir penelitian: Studi evaluasi eliminasi filariasis di Indonesia tahun 2017 (Studi Multicenter Filariasis), Area Penelitian Kabupaten Kuantan Singingi, Riau. Baturaja; 2017.

8. Irish $\mathrm{SR}, \mathrm{Al}-\mathrm{Amin} \mathrm{HM}$, Paulin $\mathrm{HN}$, et al Molecular xenomonitoring for Wuchereria bancrofti in Culex quinquefasciatus in two districts in Bangladesh supports transmission assessment survey findings. PLoS Negl Trop Dis. 2018;12(7):1-12. doi:10.1371/journal.pntd.0006574

9. Santoso, Yahya, Ambarita LP, Budiyanto A, Suryaningtyas NH, I Gede Wempi DSP D. Evaluasi penularan filariasis limfatik di Provinsi Riau dan Bangka Belitung: Parasit pada manusia dan reservoir. Balaba J Litbang Pengendali Penyakit Bersumber Binatang Banjarnegara. 2019:115-124. doi:10.22435/blb.v15i2.1625

10. Qiang Gao, Fei Wan, Xihong Lv, Hui Cao, Jianjun Zhou, Fei Su et al. Comparison of the human-baited double net trap with the human landing catch for Aedes albopictus monitoring in Shanghai, China. Parasites and Vectors. 2018;11(1):1-12. doi:10.1186/ s13071-018-3053-8

11. H. Richardson. Rampa Rattanarithikul Ralph E. Harbach Bruce A. Harrison Prachong Panthusiri Russell E. Coleman Jason. Illustrated Key to the mosquitoes of Thailand. VI. (Supavej S, ed.). Thailand: SEAMEO Regional Tropical Medicine and Public Health Network; 2010.

12. Jourdain F, Picard M, Sulesco T, Haddad N3, Harrat Z, Sawalha SS, Günay F et al. Identification of mosquitoes (Diptera: Culicidae): an external quality assessment of medical entomology laboratories in the MediLabSecure Network. Parasites and Vectors. 2018;11(1):1-7. doi:10.1186/ s13071-018-3127-7

13. Dyab AK, Galal LA, Mahmoud AES, Mokhtar Y. Xenomonitoring of different filarial nematodes using single and multiplex PCR in mosquitoes from assiut governorate, Egypt. Korean J Parasitol. 2015;53(1):77-83. doi:10.3347/kjp.2015.53.1.77

14. Heym EC, Kampen H, Krone O, Schäfer M, Werner D. Molecular detection of vectorborne pathogens from mosquitoes collected in two zoological gardens in Germany. Parasitol Res. 2019;118(7):2097-2105. doi:10.1007/s00436-019-06327-5

15. Perwitasari D, Res RN, Ariati J, et al. Detection of dengue virus using a fielddeployable PCR system: Evaluation on human serum samples in Indonesia. SoutheaSt aSian J trop Med public Heal. 2019;50(6).

16. Retno Hestiningsih, Elsye Giovanny Puspitasari, Martini, Atik Mawarni SP. Populasi Culex sp sebagai vektor filariasis. Ilm Stikes Kendal. 2019;9(2):165-174.

17. Rahmayanti A, Pinontoan O, Sondakh R. Survei dan pemetaan nyamuk Culex spp di Kecamatan Malalayang Kota Manado Sulawesi Utara. Public Heal J. 2017;6(3):1-8.

18. Zen S. Studi komunitas nyamuk penyebab filariasis di Desa Bojong Kabupaten Lampung Timur. BIOEDUKASI (Jurnal Pendidik Biol. 2015;6(2):129-133. doi:10.24127/bioedukasi.v6i2.341

19. Pratiwi R, Anwar C, Salni, Hermansyah, Novrikasari, Hidayat R et al. Diversity and abundance model according to habitat characteristics of filariasis vector, Mansonia spp. in Banyuasin, South Sumatera, Indonesia. J Phys Conf Ser. 2019;1246(1). doi:10.1088/1742-6596/1246/1/012039

20. Adnyana NWD, M . Laumalay H, Tallan MM. Penentuan nyamuk Anopheles spp sebagai vektor filariasis di Kabupaten Sumba Timur dan Sumba Barat Provinsi Nusa Tenggara Timur. Media Penelit dan Pengemb Kesehat. 2019;29(2):177-188. doi:10.22435/mpk.v29i2.281

21. Mulyaningsih B, Umniyati SR, Hadisusanto S, Edyansyah E. Study on vector mosquito of zoonotic Brugia malayi in Musi Rawas, South Sumatera, Indonesia. Vet World. 2019;12(11):1729-1734. doi:10.14202/vetworld.2019.1729-1734

22. Portunasari WD, Kusmintarsih ES, Riwidiharso E. Survei Nyamuk Culex spp. sebagai Vektor Filariasis di Desa Cisayong, Kecamatan Cisayong, Kabupaten 
Tasikmalaya. Biosfera. 2017;33(3):142. doi:10.20884/1.mib.2016.33.3.361

23. Yulidar. Populasi nyamuk yang berpotensi sebagai vektor filariasis di Kabupaten Aceh Utara. J Biot. 2018;6(1):70-74.

24. Istianah S, Mulyaningsih B, Umniyati SR. Diversity and activities of mosquito in Yogyakarta Special Region Province, Indonesia, a non filariasis endemic area. E3S Web Conf. 2020;151:1-4. doi:10.1051/ e3sconf/202015101016

25. Fitriyana F, Sukendra DM, Windraswara R. Distribusi Spasial vektor potensial filariasis dan habitatnya di daerah endemis. HIGEIA (Journal Public Heal Res Dev. 2018;2(2):320-330. doi:10.15294/higeia.v2i2.17851

26. Maryanti E, Andriyani A, Suyanto S. Gambaran penderita filariasis di Kabupaten Meranti Provinsi Riau Periode 2009-2014. J Ilmu Kedokt. 2017;10(2):112. doi:10.26891 /jik.v10i2.2016.112-120

27. Dorkenoo MA, De Souza DK, Apetogbo Y, et al. Molecular xenomonitoring for postvalidation surveillance of lymphatic filariasis in Togo: No evidence for active transmission. Parasites and Vectors. 2018;11(1):1-9. doi:10.1186/s13071-0172611-9

28. Salim MF, Baskoro T, Satoto T, Kusnanto H.
Zona Kerentanan filariasis berdasarkan faktor risiko dengan pendekatan sistem informasi geografis. J Inf Syst Public Heal. 2016;1(1):16-24.

29. Ridha MR, Sembiring WRG. Perilaku mengisap darah dan perkiraan umur populasi di alam nyamuk potensial vektor filariasis di Desa Dadahup, Kabupaten Kapuas, Kalimantan Tengah. J Vektor Penyakit. 2019;13(2):77-86. doi:10.22435/ vektorp.v13i2.1008

30. Munawwaroh L, Pawenang ET. Evaluasi program eliminasi filariasis dari aspek perilaku dan perubahan lingkungan. Unnes J Public Heal. 2017;5(3):195. doi:10.15294 /ujph.v5i3.10013

31. Supriyono S, Tan S, Hadi UK. Perilaku nyamuk mansonia dan potensi reservoar dalam penularan filariasis di Desa Gulinggang Kabupaten Balangan Provinsi Kalimantan Selatan. ASPIRATOR - J Vectorborne Dis Stud. 2017;9(1):1-10 doi:10.22435/aspirator.v9i1.4443.1-10

32. Santoso S, Yahya Y, Ambarita LP, et al. Evaluasi penularan filariasis limfatik di Provinsi Riau dan Bangka Belitung: Parasit pada manusia dan reservoir. Balaba J Litbang Pengendali Penyakit Bersumber Binatang Banjarnegara. 2019:115-124. doi:10.22435/blb.v15i2.1625 